\title{
NEW COMPOSITE LEADING INDICATOR OF THE HUNGARIAN BUSINESS CYCLE*
}

\author{
Andrea TKÁČOVÁ - Marianna SINIČÁKOVÁ \\ (Received: 26 March 2013; revision received: 15 July 2013; \\ accepted: 21 September 2013)
}

\begin{abstract}
The objective of the paper is to create a composite leading indicator (CLI) for monitoring and predicting Hungarian business cycles. We compare the existing CLI applied by the OECD and Eurostat with our own CLI. According to our findings, our CLI forecasts the evolution of a referential series more precisely than the CLIs developed by the OECD and Eurostat. Nevertheless, from our point of view, the application of all existing CLIs at the same time can be appropriate. Consequently, the number of false signals should be reduced. The CLIs allow us to receive the first rough preliminary estimations of an economic cycle, in our case, the Hungarian one.
\end{abstract}

Keywords: leading indicators, composite leading indicator, business cycle, reference series, GDP, industrial production index, Hungary

JEL classification indices: E3, E32

* The paper was elaborated within the project of Scientific Grant Agencies (VEGA) No. $1 / 0994 / 15$.

Marianna Siničáková, corresponding author. Associate Professor at Faculty of Economics, Technical University of Košice (TUKE), Košice, Slovakia. E-mail: marianna.sinicakova@tuke.sk

Andrea Tkáčová, Assistant Professor at Faculty of Economics, Technical University of Košice (TUKE), Košice, Slovakia. E-mail: andrea.tkacova@tuke.sk 


\section{INTRODUCTION}

Several approaches have been developed for monitoring business cycles - most of them are based on Burns - Mitchell (1946) or Moor (1961). These authors set down the fundamental principles of composite leading indicators that enable us to identify individual cycles. The key element of this approach is to create groups of cyclical indicators, which have the capacity to reveal the positions of an economy within its cyclical evolution. These business cycle indicators allow us to determine the actual phase and to predict the possible future business cycle evolution.

At present, business cycle monitoring via composite leading indicators is in the focus of international organisations such as the OECD, Eurostat, Conference Board, etc. Nevertheless, their methodologies have certain particularities, which can be crucial for creating an adequate composite leading indicator for the Hungarian economy.

Our contribution to the existing literature is to suggest a quantifiable composite leading indicator (CLI) convenient for monitoring and for the short-term prediction of economic evolution in Hungary after taking into account the particularities of the Hungarian economy (see Györffy 2009), which would be an adequate alternative to the CLIs applied by the OECD or Eurostat.

\section{THEORETICAL BACKGROUND OF THE COMPOSITE LEADING INDICATOR}

At first sight, it might seem that interpretations of composite indicators (CI) are obvious and easier than the interpretation of partial indicators. However, it is necessary to interpret CI evolution together with the evolution of its partial components. Thus, its accountability and relevance is higher. The incorrect formulation and consequent analysis of the composite indicator could lead to mistaken political and economic decisions (Saltelli 2007). The more complex an indicator, the better it describes an economy. However, more complex indicators are often limited in their public availability and flexibility (Macháčková et al. 2007).

Various institutions and countries evaluate and predict economic reality using their own composite indicators comprising data from different sources. Data often come from conjectural research outputs, traditional real economy indicators, financial indicators, monetary aggregates, prices, and other external indicators according to the individual needs of institutions and countries. The mathematical formulations and contents of composite indicators are not strictly determined. Their creation depends on users (NBS 2006). Nardo - Saisana (2005) propose a 
precise composite indicator formulation process consisting of specific steps. According to the OECD, the content of the composite indicators should respect the particularities of each economy. In contrast, the Eurostat prefers the application of a common composite indicator for different countries.

An important step in creating a composite indicator is to gather cyclical indicators into several groups that have a strong relationship with the business cycle evolution of the chosen economy. Generally speaking, three groups of cyclical indicators are determined, i.e. leading, coincident and lagging indicators (OECD 1993). These types of indicators reflect their relationships to economic evolution. Economic evolution is mostly expressed via GDP. Thus, GDP represents a referential time series. Indicators that follow the evolution of a referential time series are called coincident indicators. These indicators confirm or deny a certain position of an economy (OECD 1993). Values of certain cyclical indicators have different time trajectories than indicators focusing on GDP evolutions. Some indicators have the capacity to evolve in advance compared to economic evolution. Therefore, it is possible to apply them for short-term predictions (Sullinav - Sheffrin 2003). This is the case of leading indicators. Their role is to forecast turning points of economic activity and to inform about the probable fluctuation rate of data in the referential series in each stage of a business cycle (OECD 2012a). They enable us to predict growth or contraction in the referential series, but not their precise values. These indicators are considered to be the most important due to their prediction ability (Mester 2007). The third group of indicators is lagged towards real economic activity. Thus, they are called as lagging indicators. They help us to verify a previous cycle (its turning points) (Czesány - Ježábková 2009).

The character of composite indicators depends on the type of chosen cyclical indicators. It means that it is possible to create a composite coincident indicator on the basis of coincident indicators' group, a composite lagging indicator from the group of lagging indicators, and a composite leading indicator using the group of leading indicators. In terms of short-term prediction, the composite leading indicator (CLI) is the most important one. The CLI represents an aggregate time series that is leading in advance in regard to a referential series corresponding to the business cycle of a chosen economy (OECD 2012b). The combination of several leading indicators offers more precise predictions than separate leading indicators. However, CLIs cannot fully replace econometric models in the field of long-term predictions. The role of CLIs is only complementary to econometric models in long-run predictions (OECD 1998).

The first CLI was suggested by Moore (1961) from the Economic Cycle Research Institute. Later, he modified the original CLI to an index of leading economic indicators (LEI). Consequently, many economists have focused on leading 
cyclical indicators to predict business cycle (Economic Cycle Research Institute 2011) and on cycles and shocks with respect to different relevant variables, e.g. investments (Mihályi 1988).

\section{THE CLI FORMULATION AND COMPARISON IN THE CASE OF HUNGARY}

Hungarian business cycles can be monitored through the CLIs developed by the OECD and Eurostat. Their calculations and formulations are different. However, current studies do not mention their prediction capacities in respect of the business cycle. Therefore, we analyse the CLIs of these international institutions. Above all, we take into account size (number of leading months or quarters) and accuracy, i.e. the quality of leading series in regard to referential series. The quality can be measured using a correlation coefficient.

\subsection{The OECD methodology}

The OECD methodology is based on growth cycles. It stems from an assumption that a time series can be divided into a random, trend and cyclical part. First, the OECD applied the modified phase-average trend (PAT) methodology developed by the American National Bureau of Economic Research (NBER). Boschan Ebanks (1978) find the methodology mathematically and statistically demanding. Trend calculation is based on calculations of time series moving averages (Nilsson - Gyomai 2007).

In 2008, the OECD replaced the PAT methodology with the Hodrick-Prescott (HP) filter. The main reason for the change is that the HP filter is able to eliminate trend component and to smooth the whole time series in one step (Schlicht 2005). The PAT methodology required one more procedure to smooth a series via moving averages (OECD 2012a). The advantage of the HP filter is that it is not demanding regarding input data (Bezděka et al. 2003). Beneš - N'Diaye (2004) consider the HP filter to be the simplest alternative to modern filtering techniques. The HP filter can be easily applied to any time series (Hodrick - Prescott 1997). The parameter $\lambda$ has to be determined. It optimises trend smoothing (Fabiani Mestre 2000). The parameter $\lambda$ equals $100,1,600$ and 14,400 in cases of annual, quarterly and monthly data, respectively. These values are based on the empirical observations of Hodrick - Prescott (1997). The disadvantage of the HP filter is that results are biased at the beginning and end of the observed series. This is the so-called problem of end-points (Trimbur 2006). The time series is enlarged 
by predictions to reduce the problem with end-points (Zimková - Barochovský 2007).

The OECD applies the index of industrial production as a referential series since it is available with a higher frequency than GDP. According to the OECD, it is not possible to formulate the same composite indicators for different economies. Thus, it uses various groups of leading indicators. The most often applied are business surveys, monetary and financial indicators, stocks and orders, retail sales, prices, and external trade indicators (OECD 2008).

The OECD is the only institution that implements indicators linked to the external economy, e.g. external trade, evolution of exportations, and exchange rates. It combines soft (qualitative) and hard (quantitative) data in its research. Particular indicators have the same weights. Different weights would minimise the impact of those indicators that do not reflect the same direction as other indicators. Consequently, the reliability of composite indicators could be reduced. Their significance in one cycle would be different as in another one (Gyomai - Guedette 2012). As reported by Nilsson (2000), the OECD indicators have a better reliability than the Eurostat indicators.

At present, the CLI for Hungary developed by the OECD comprises seven indicators (OECD 2013):

1. production in the manufacturing industry (future evolution in $\%$ ),

2. registered number of the unemployed,

3. number of working hours per month in the manufacturing industry,

4. monetary aggregate M1 (HUF),

5. BSE (Budapest Stock Exchange) index $(2005=100)$,

6. central bank base rate $(\%)$, and

7. total imports (HUF).

The Evolution of the OECD CLI and of the industrial production index is captured in Figure 1. We can observe a certain leading trend of the CLI towards a referential series evolution, especially before and during financial and economic crisis.

The cross-correlations of the observed time series were calculated to verify the statistically leading and prediction capacity of the CLI. Results are presented in Table 1.

The OECD CLI allows us to study a referential series evolution three months in advance. However, the accuracy of leading capacity, measured through the value of the correlation coefficient, depends on the time series length. The CLI corresponds rather to the shorter time series of Hungarian business cycle (2005-2011) than to the longer one (2001-2011). These findings reflect a changing economic situation. Thus, the current formulation of the CLI does not have to be suitable for the past. 

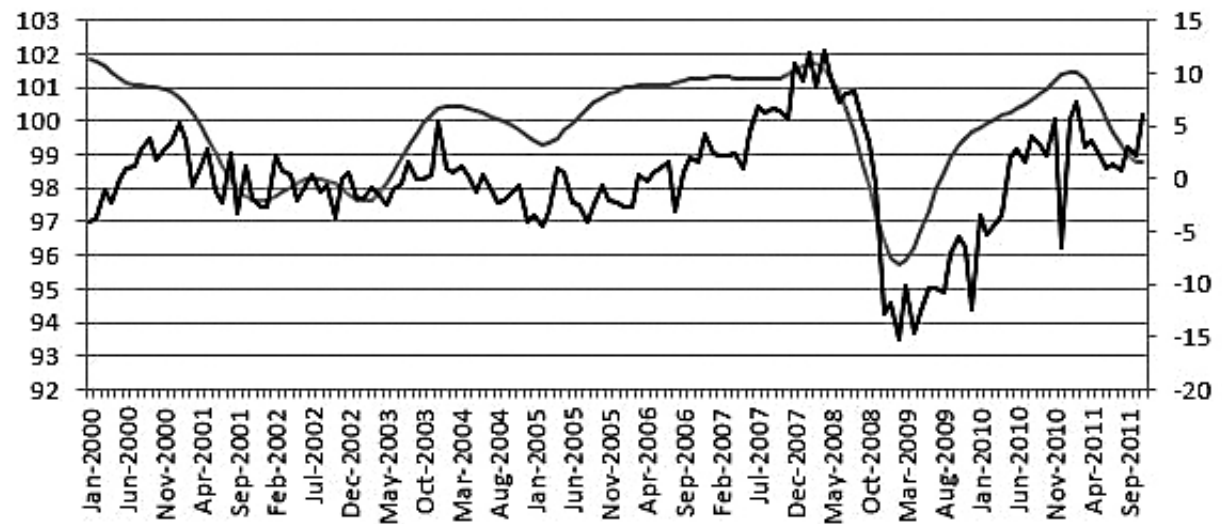

CLIOECD

- industrial production index

Figure 1. The OECD CLI and industrial production index (cyclical component) in Hungary Source: Own calculations according to the OECD data.

Table 1

Cross-correlation results between the OECD referential series and CLI (M1 2005-M12 2011)

\begin{tabular}{|l|c|c|c|c|c|c|c|c|c|c|c|c|c|}
\hline Period & $t-12$ & $t-11$ & $t-10$ & $t-9$ & $t-8$ & $t-7$ & $t-6$ & $t-5$ & $t-4$ & $t-3$ & $t-2$ & $t-1$ & $\mathrm{t}$ \\
\hline $\begin{array}{l}\text { M1 } \\
\begin{array}{l}\text { 2000-M12 } \\
2011\end{array}\end{array}$ & 0.262 & 0.301 & 0.331 & 0.395 & 0.462 & 0.526 & 0.582 & 0.630 & 0.664 & $\mathbf{0 . 6 7 9}$ & 0.677 & 0.646 & 0.589 \\
\hline $\begin{array}{l}\text { M1 2005 } \\
- \text { M12 2011 }\end{array}$ & 0.420 & 0.432 & 0.405 & 0.487 & 0.568 & 0.645 & 0.714 & 0.770 & 0.808 & $\mathbf{0 . 8 2 3}$ & 0.815 & 0.780 & 0.716 \\
\hline
\end{tabular}

Note: M1and M12 is January and December of the particular year, respectively.

Source: Own calculations.

Table 2

Cross-correlation results between the OECD referential series and CLI (Q1 2000-Q4 2011)

\begin{tabular}{|l|c|c|c|c|c|c|c|c|c|}
\hline Period & $t-4$ & $t-3$ & $t-2$ & $t-1$ & $t$ & $t+1$ & $t+2$ & $t+3$ & $t+4$ \\
\hline $\begin{array}{l}\text { Q1 2000- } \\
\text { Q4 2011 }\end{array}$ & 0.496 & 0.660 & $\mathbf{0 . 7 6 4}$ & 0.753 & 0.586 & -0.104 & $\mathrm{v} 0.037$ & -0.069 & -0.151 \\
\hline $\begin{array}{l}\text { Q1 2005- } \\
\text { Q4 2011 }\end{array}$ & 0.410 & 0.647 & 0.827 & $\mathbf{0 . 8 7 3}$ & 0.737 & 0.446 & 0.054 & -0.268 & -0.457 \\
\hline
\end{tabular}

Note: Q1 and Q4 is the first and last quarter of the particular year, respectively.

Source: Own calculations. 
In addition to the monthly prediction, we have recalculated the values of the OECD CLI and industrial production index on the quarterly basis (see Table 2). Thus, the results can be compared to the Eurostat data.

Recalculations to quarterly data enable us to reduce the presence of extreme values. Time series are more smoothed and their correlation coefficients reach higher values in the same leading period (1-2 quarters).

\subsection{The Eurostat methodology}

Eurostat also analyses cyclical evolution of an economy via growth cycle. Trend estimation is calculated through the Christiano-Fitzgerald filter of random walk. This filter is constructed on the same principles as the Baxter-King filter (Everts 2006). The advantage of the Christiano-Fitzgerald filter is that it is designed to work well with longer time series than the Baxter-King filter. In addition, it converges in the long run to the optimal filter, and in real time applications outperforms the Baxter-King filter (Nilsson - Gyomai 2011).

GDP at constant prices is chosen as a referential time series. Eurostat determines a single composite leading indicator for all observed countries. This indicator comprises:

1. industrial confidence indicator,

2. consumer confidence indicator, construction confidence indicator, and

3. share prices indicator (Czesaný 2006).

According to the Eurostat approach, the composite indicator formulation is based on soft data, i.e. the combination of qualitative and quantitative ones (Ozyildirim et al. 2009). Eurostat applies a simple system of weights where particular components are divided into two groups. The second group (construction confidence indicator and share prices indicator) has half a weight compared to the first group (industrial confidence indicator, consumer confidence indicator). The advantage of the European Union is that all the components are easily available.

It is necessary to construct the CLI for Hungarian economy according to the Eurostat approach in order to verify the prediction capacities of the indicator. Unlike the OECD, Eurostat does not provide us with the CLI evolution of Hungarian economy. GDP cyclical component at constant prices $(2005=100)$ was chosen as a referential series. The cyclical component was calculated via the ChristianoFitzgerald filter. The CLI by Eurostat and the referential series evolution are depicted in Figure 2.

The cross-correlations were calculated for three different time series (Table 3). The shorter time series was observed the higher correlation coefficient was found. It means that the current CLI composition corresponds rather to the current eco- 
nomic situation than to the past. However, the correlation coefficient at the level of 0.701 in the case of two leading quarters can create false signals about future economic development in Hungary. Consequently, it would be more appropriate to suggest a CLI tailor-made for the Hungarian economy that would predict the evolution of a referential series more precisely.

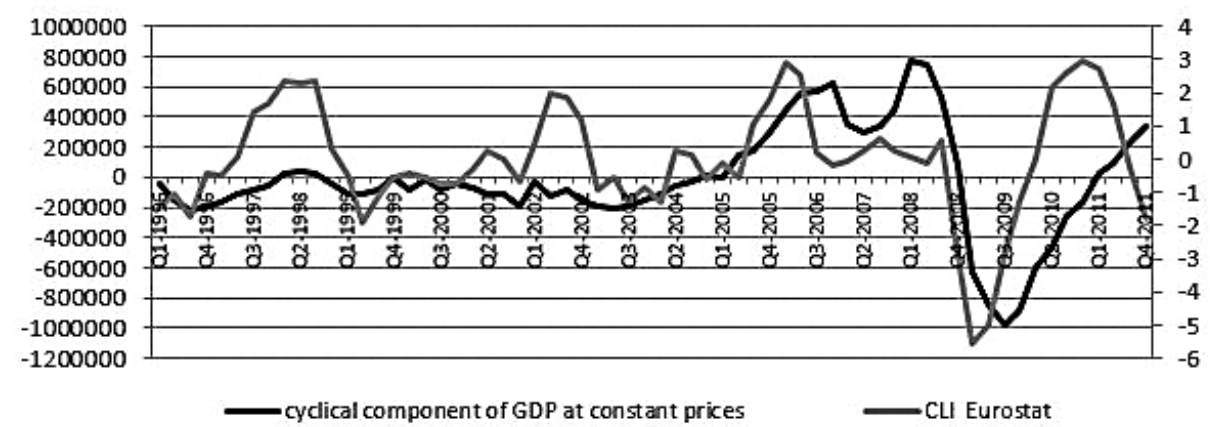

Figure 2. The Eurostat CLI and cyclical component of GDP at constant prices $(2005=100)$ in Hungary

Source: Own representation according to the Eurostat.

Table 3

Cross-correlation results between the Eurostat referential series and CLI (Q1 1996-Q4 2011)

\begin{tabular}{|l|c|c|c|c|c|c|c|c|c|}
\hline Period & $t-4$ & $t-3$ & $t-2$ & $t-1$ & $\mathrm{t}$ & $t+1$ & $t+2$ & $t+3$ & $t+4$ \\
\hline $\begin{array}{l}\text { Q1 1996- } \\
\text { Q4 2011 }\end{array}$ & 0.384 & 0.520 & 0.590 & 0.560 & 0.391 & 0.139 & -0.171 & -0.432 & -0.571 \\
\hline $\begin{array}{l}\text { Q1 2000- } \\
\text { Q4 2011 }\end{array}$ & 0.437 & 0.572 & $\mathbf{0 . 6 3 8}$ & 0.594 & 0.407 & 0.136 & -0.187 & -0.452 & -0.591 \\
\hline $\begin{array}{l}\text { Q1 2005- } \\
\text { Q4 2011 }\end{array}$ & 0.505 & 0.642 & $\mathbf{0 . 7 0 1}$ & 0.641 & 0.427 & 0.124 & -0.222 & -0.508 & -0.654 \\
\hline
\end{tabular}

Note: Q1 and Q4 is the first and last quarter of the particular year, respectively.

Source: Own calculations.

\subsection{The Conference Board methodology}

The Conference Board's (CB) main function is to monitor the evolution of the American economy and to construct cyclical indicators. Another American organisation, the Economic Cycle Research Institute, deals with the research of 
economic cycles, too. The BCI (business cycle index) simultaneously comprises leading, coincident, and lagging indicators (Conference Board 2001).

The construction of the composite leading indicator is easier. Month-on-month indicators of partial indicators are created and then they are statistically adjusted. The Conference Board formulates a referential time series as a complex economic indicator consisting of

1. industrial production indicator,

2. sales volume of manufacturing industry and trade,

3. number of employees excluding agricultural sectors, and

4. personal income excluding transfer payments.

This methodology also serves as a coincident cyclical indicator.

The leading indicator for American economy involves 10 components (Conference Board 2001), namely

1. average number of working hours per week in the manufacturing industry,

2. average number of the primary applications for unemployment applications,

3. new orders in manufacturing industry,

4. delivery speed of goods to the seller,

5. value of stock index S\&P 500,

6. new construction permissions,

7. stock prices,

8. monetary aggregate M2 (supply of money),

9. spread between long- and short-term interest rates, and

10. average expectations of consumers in the field of business terms.

The Conference Board creates composite indicators respecting several principles. For instance, time series have to be in line with business cycle, the cyclical behaviour of time series has to be explained on an economic basis, statistics data have to be reliable, etc. Cyclical indicators of the American economy are based exclusively on quantitative data. The leading indicator for American economy is calculated by the Centre for International Business Cycle Research (CIBCR), too. This composite indicator includes twelve partial indicators and is also based exclusively on hard data.

\subsection{Comparisons of the CLI formulations}

The deteils of the CLI formulations differ in several aspects. We can distinguish several approaches according to the choice of a referential series, types of data, time series adjustment, weight determination, etc. Thus, the quality of a CLI can 
vary significantly, depending on the right choice. The main differences among methodologies applied by the OECD, Eurostat, and the Conference Board are mentioned in Table 4.

\section{Table 4}

Comparison of composite leading indicator formulations

\begin{tabular}{|l|l|l|l|}
\hline Criteria & OECD & Eurostat & Conference Board \\
\hline Business cycle & growth cycle & growth cycle & growth cycle \\
\hline Observed countries & $\begin{array}{l}\text { the OECD member } \\
\text { countries and chosen } \\
\text { non-member countries }\end{array}$ & $\begin{array}{l}\text { chosen EU countries } \\
\text { (apart from Slovakia), } \\
\text { Euro area... }\end{array}$ & $\begin{array}{l}\text { U.S., Canada, Mexico, } \\
\text { Brazil, Japan, China, } \\
\text { India... }\end{array}$ \\
\hline Trend elimination & $\begin{array}{l}\text { Hodrick-Prescott (HP) } \\
\text { filter }\end{array}$ & $\begin{array}{l}\text { Christiano-Fitzgerald } \\
\text { filter }\end{array}$ & $\begin{array}{l}\text { Phase-Average-Trend } \\
\text { (PAT) methodology }\end{array}$ \\
\hline Referential series & $\begin{array}{l}\text { industrial production } \\
\text { index (up to March } \\
\text { 2012), monthly GDP at } \\
\text { constant prices (since } \\
\text { March 2012) }\end{array}$ & $\begin{array}{l}\text { quarterly GDP at con- } \\
\text { stant prices }\end{array}$ & complex indicator \\
\hline $\begin{array}{l}\text { Relationship between } \\
\text { a referential series } \\
\text { and indicators }\end{array}$ & cross-correlation & $\begin{array}{l}\text { methodology is not } \\
\text { based on relationship } \\
\text { determination }\end{array}$ & $\begin{array}{l}\text { methodology is not } \\
\text { based on relationship } \\
\text { determination }\end{array}$ \\
\hline Type of data & $\begin{array}{l}\text { qualitative and quanti- } \\
\text { tative data }\end{array}$ & $\begin{array}{l}\text { qualitative and quanti- } \\
\text { tative data }\end{array}$ & quantitative data \\
\hline $\begin{array}{l}\text { Weight determina- } \\
\text { tion }\end{array}$ & $\begin{array}{l}\text { particular components } \\
\text { are divided into two } \\
\text { the same weights } \\
\text { group has a half weight } \\
\text { compared to the first } \\
\text { group }\end{array}$ & $\begin{array}{l}\text { based on weight deter- } \\
\text { mination }\end{array}$ \\
\hline CLI composition & $\begin{array}{l}\text { different elements of } \\
\text { the CLI according to a } \\
\text { country }\end{array}$ & $\begin{array}{l}\text { the same CLI composi- } \\
\text { tion for all countries }\end{array}$ & $\begin{array}{l}\text { different elements of } \\
\text { the CLI according to a } \\
\text { country }\end{array}$ \\
\hline
\end{tabular}

Source: Own comparisons.

\section{THE CLI CONSTRUCTION IN THE CASE OF HUNGARIAN BUSINESS CYCLES}

\subsection{Choice of a referential series}

It is necessary to choose a right referential series representing the Hungarian business cycle. The OECD recommends application of GDP (Tuveri 1997). However, the indicator is available only on a quarterly basis. Consequently, the OECD preferred the industrial production index up to March 2012. GDP recalculated 
to a monthly period has been applied by the OECD since 2012 (OECD 2012b). Eurostat uses GDP at constant prices (its cyclical component). The third possibility is to create an own composite indicator. This solution is preferred by the Conference Board.

The economic significance of particular indicators is one of the important factors that influence the choice of a referential series. GDP relevance is obvious as it is a main business cycle indicator. The industrial production index is also important as it expresses the evolution of industry, which represents a significant part of GDP. The correlation coefficient between the Hungarian GDP and the industrial production index is 0.983 . The cyclical components of time series are used to observe the cyclical evolution of an economy. Thus, we calculated the correlation between the cyclical components of GDP and the industrial production index. The value of the correlation coefficient was 0.841 . These values correspond to the period from Q1 1995 to Q4 2011. However, results in the case of shorter time series can be different. Therefore, we also calculated cross-correlations for the period 2000-2005.

Table 5 reflects that the industrial production index corresponds to GDP evolution during all observed periods. Consequently, the industrial production index can be applied as a referential series for the Hungarian economy. $t+$ values prove that the industrial production index has attributes of coincident indicator and does not correspond either to leading or lagging indicator. This finding is in line with the OECD approach. In addition, the OECD CLI has good prediction capacities. On the other hand, the Eurostat CLI is weaker in predictions than the OECD CLI as it is obvious from Tables 2 and 3. Cross-correlations confirm this opinion. Therefore, it would be more appropriate to analyse the relationship of particular indicators to GDP and to formulate a CLI that can predict Hungarian business cycles more precisely and on a quarterly basis. The creation of an own composite indicator that would be in the position of a referential series is rather complicated and does not guarantee better predictions. Due to these facts, we apply the cyclical component of GDP at constant prices as a referential series.

\subsection{Methodology of the CLI formulation}

The formulation of an own CLI is based on growth cycles, which is more appropriate in the case of transition economies with a higher rate of growth (Macháčková et al. 2007). After the collection of time series databases, the following steps have to be carried out (Tkáčová 2012): 
1. Seasonal adjustment of time series (seasonal indices) - Seasonal indices enable us to adjust time series and gain a cyclical component from original data.

2. Trend elimination (Hodrick-Prescott filter) - One of the reasons for the choice of the HP filter is that it eliminates trend component in one operation and it smooths the whole time series in the same step (Schlicht 2005). Thus, it is possible to obtain the cyclical components of time series that are required for business cycle analysis.

3. Cross-correlation - It allows us to express the relationship between a referential series and time series of cyclical indicators that we observe. Cross-correlations are carried out with five-period forward and backward looking shift. The linear relationship between variables is expressed via the Pearson correlation coefficient (Marek 2007). The application of the Pearson correlation coefficient requires normal distribution of analysed variables. At the same time, stationarity has to be ensured. Generally speaking, non-stationarity (presence of a unit root) is typical for economic time series. Non-stationarity of level values can be eliminated, e.g., by first or second differences, or logarithmic transformation. Consequently, correlation can be calculated.

4. Creation of cyclical indicators groups (coincident, lagging, leading) - According to the value of the correlation coefficient, we can create three groups of cyclical indicators. Cyclical indicators have to be in line with the following requirements:

- Coincident indicators - The highest absolute value of the correlation coefficient is in time $t$ and the second highest absolute value of the correlation coefficient has to be at least 0.55 . This value is in line with the recommendations of Klúčik (2009), who created the CLI for Slovakia, and with Czesaný - Jeřábková (2009) who suggested their CLI for the Czech Republic.

Table 5

Cross-correlation results between GDP and industrial production index cyclical components

\begin{tabular}{|l|c|c|c|c|c|c|c|c|c|}
\hline Period & $t-4$ & $t-3$ & $t-2$ & $t-1$ & $t$ & $t+1$ & $t+2$ & $t+3$ & $t+4$ \\
\hline $\begin{array}{l}\text { Q1 1995- } \\
\text { Q4 2011 }\end{array}$ & 0.105 & 0.394 & 0.652 & 0.810 & $\mathbf{0 . 8 4 1}$ & 0.702 & 0.482 & 0.258 & 0.088 \\
\hline $\begin{array}{l}\text { Q1 2000- } \\
\text { Q4 2011 }\end{array}$ & 0.110 & 0.399 & 0.653 & 0.807 & $\mathbf{0 . 8 4 0}$ & 0.707 & 0.492 & 0.274 & 0.104 \\
\hline $\begin{array}{l}\text { Q1 2005- } \\
\text { Q4 2011 }\end{array}$ & 0.140 & 0.439 & 0.704 & 0.861 & $\mathbf{0 . 8 8 9}$ & 0.739 & 0.500 & 0.251 & 0.057 \\
\hline
\end{tabular}

Note: Q1 and Q4 is the first and last quarter of the particular year, respectively.

Source: Own calculations. 
- Lagging indicators - The highest absolute value of the correlation coefficient is situated on the right side from $t$ and the second highest absolute value of the correlation coefficient has to be at least 0.55 .

- Leading indicators - The highest absolute value of the correlation coefficient is situated on the left side from $t$ and the second highest absolute value of the correlation coefficient has to be at least 0.55 .

5. Normalisation of data (standardisation) - Normalisation of data enables us to use data in different units. In our case, we will apply standardisation of a time series using the following relationship (OECD 2008):

$$
I_{q c}^{t}=\frac{x_{q c}^{t}-x_{q c=\bar{c}}^{t}}{\sigma_{q c=\bar{c}}^{t}}
$$

where $I_{q c}^{t}$ is a normalised value, $x_{q c}^{t}$ is a real value, $x_{q c \bar{c}}^{t}$ is an average value, and $\sigma_{q c=\bar{c}}$ represents standard deviation. This manner of standardisation is recommended, e.g. by OECD (2008), among several others approaches.

6. Weight determination - To create a CLI, we will compare the application of the same and of different weights. The same weights will be calculated according to a simple formula:

$$
v=\frac{1}{n}
$$

where $v$ is weight of each leading indicator creating the composite leading indicator and $n$ is a number of the leading cyclical indicators. Particular weights are determined according to the correlation coefficient absolute values. Higher weights will be associated to indicators with higher correlation coefficients. The calculation of different weights can be represented via:

$$
v_{i}=\frac{r_{i}}{\sum_{i=1}^{n} r_{i}}
$$

where $v_{i}$ is weight of a leading indicator $i$, and $r_{i}$ is a correlation coefficient value of a leading indicator $i$ in a lead-time.

7. The CLI formulation - The CLI will be based on the sum of the indicators multiplied by their weights. 


\subsection{Hungarian cyclical indicators}

Hungarian cyclical indicators retrieved from the OECD, Eurostat and Hungarian Central Statistical Office were observed for the purpose of the study. We investigated the cyclical behaviour of 116 indicators. We determined GDP as a referential time series and we examined the cross-correlations of GDP with the chosen indicators. According to their cross-correlations results, the indicators were divided into four groups: coincident, lagging, leading indicators and indicators without any evident relationships with referential series.

In the case of Hungary, 17 various items were involved in the group of coincident indicators. They were mostly industrial indicators. Thus, we can conclude that this part of the Hungarian economy evolves in line with its business cycle. Eight lagging indicators were analysed in the Hungarian business cycle. The leading indicators represent the most interesting category for us. This group consists only of six items in the case of Hungary. Therefore, only a small number of economic variables are able to predict Hungarian business cycle evolution.

\subsubsection{The Hungarian CLI construction}

Our methodology enabled us to identify six leading indicators for Hungarian business cycle:

1. Budapest Stock index, 2005 $=100$,

2. market capitalisation in current prices, billions of euro,

3. construction labour input index, $2005=100$,

4. crude steel production, thousands of tons,

5. industrial confidence indicator, and

6 . services confidence indicator.

The identified indicators were not numerous, yet they covered almost the whole economy. The Budapest Stock index and market capitalisation have a similar economic significance. Thus, to avoid duplicating, market capitalisation was excluded. We had several reasons for the exclusion. First, the two indicators have a very similar meaning from the economic point of view. Second, market capitalisation reached lower values of cross-correlations than the Budapest Stock index. The third argument is that even the OECD and Eurostat include only the Budapest Stock index in their composite indicator. Finally, the number of leading indicators included in our CLI is five.

Particular groups of indicators are represented in Table 6. Time series cover the period from 2001 to 2011. Indicators were chosen according to the value of the 
highest correlation coefficient in comparison with other leading indicators. The observed variables had a normal distribution and their stationarity was ensured via logarithmic operations. Three alternatives were chosen for the CLI.

\section{Table 6}

Alternatives of the CLI composition for Hungary

\begin{tabular}{|l|l|}
\hline CLI & Leading indicators \\
\hline CLI 1/CLI A & $\begin{array}{l}\text { Budapest Stock index, 2005 }=100 \\
\text { Construction labour input index (overall), 2005 }=100 \\
\text { Crude steel production, thousands of tons } \\
\text { Industrial confidence indicator } \\
\text { Services confidence indicator }\end{array}$ \\
\hline CLI 2/CLI B & CLI 1 - Industrial confidence indicator \\
\hline CLI 3/CLI C & CLI 2 - Crude steel production, thousands of tons \\
\hline
\end{tabular}

Note: CLI 1, 2 and 3 have the same weights; CLI A, B and C have different weights.

Source: Own comparisons.

Firstly, we have calculated cross-correlations using the same weights for particular CLI. The second approach was based on the application of different weights according to the value of the correlation coefficients. Table 7 captures cross-correlation results in the case of the same weights.

\section{Table 7}

Cross-correlation results in the case of the same weights for three alternatives of the Hungarian CLI

\begin{tabular}{|l|c|c|c|c|c|c|c|c|c|c|}
\hline CLI & $t-4$ & $t-3$ & $t-2$ & $t-1$ & $t$ & $t+1$ & $t+2$ & $t+3$ & $t+4$ \\
\hline \multicolumn{1}{|c|}{ Cross-correlation results for the period Q1 2001-Q4 2011 } \\
\hline CLI 1 & 0.514 & 0.717 & 0.850 & $\mathbf{0 . 8 7 1}$ & 0.735 & 0.480 & 0.171 & -0.099 & -0.254 \\
\hline CLI 2 & 0.506 & 0.718 & 0.862 & $\mathbf{0 . 8 9 9}$ & 0.775 & 0.533 & 0.231 & -0.040 & -0.202 \\
\hline CLI 3 & 0.606 & 0.786 & $\mathbf{0 . 8 8 7}$ & 0.878 & 0.727 & 0.483 & 0.188 & -0.082 & -0.256 \\
\hline \multicolumn{10}{|c|}{ Cross-correlation results for the period Q1 2005-Q4 2011 } \\
\hline CLI 1 & 0.467 & 0.694 & 0.851 & $\mathbf{0 . 8 7 6}$ & 0.742 & 0.506 & 0.233 & 0.004 & -0.112 \\
\hline CLI 2 & 0.532 & 0.740 & 0.878 & $\mathbf{0 . 9 0 1}$ & 0.761 & 0.504 & 0.191 & -0.085 & -0.245 \\
\hline CLI 3 & 0.583 & 0.786 & $\mathbf{0 . 8 9 8}$ & 0.884 & 0.723 & 0.460 & 0.164 & -0.082 & -0.220 \\
\hline
\end{tabular}

Note: Cross-correlations were calculated from time series Q1 2001-Q4 2011. Q1 and Q4 is the first and last quarter of the particular year, respectively.

Source: Own calculations.

Table 7 represents particular alternatives of the CLI. They differ in their leadtime length and correlation coefficients values. A lead-time at the level of one quarter was obvious in CLI 1 and CLI 2. A two-trimestral lead-time was ob- 
served in CLI 3. In the case of CLI 2, the highest correlation coefficient value was 0.899. This composition of the CLI should be the most appropriate for short-run prediction and referential series monitoring in Hungary. According to the crosscorrelation results since 2005, CLI 2 seems to be again the most convenient. If the weights are the same, the Hungarian CLI can be formulated as:

$\mathrm{CLI}_{\text {HUNGARY (same weights) }}=0.25 *$ Budapest Stock index $+0.25 *$ crude steel production + $0.25 *$ construction labour input index $+0.25 *$ service confidence indicator

On the other hand, weights can be determined according to correlation coefficients. Table 8 depicts cross-correlations results of particular CLIs with the Hungarian referential series.

Table 8

Cross-correlation results in the case of different weights for three alternatives of the Hungarian CLI

\begin{tabular}{|l|l|l|l|l|l|l|l|l|l|l|}
\hline CLI & $t-4$ & $t-3$ & $t-2$ & $t-1$ & $t$ & $t+1$ & $t+2$ & $t+3$ & $t+4$ \\
\hline \multicolumn{8}{|c|}{ Cross-correlation results for the period Q1 2001-Q4 2011 } \\
\hline CLI A & 0.473 & 0.691 & 0.820 & $\mathbf{0 . 8 2 5}$ & 0.659 & 0.386 & 0.077 & -0.170 & -0.283 \\
\hline CLI B & 0.519 & 0.730 & 0.869 & $\mathbf{0 . 8 9 8}$ & 0.768 & 0.524 & 0.223 & -0.045 & -0.204 \\
\hline CLI C & 0.610 & 0.792 & $\mathbf{0 . 8 8 9}$ & 0.877 & 0.720 & 0.475 & 0.184 & -0.083 & -0.251 \\
\hline \multicolumn{8}{|c|}{ Cross-correlation results for the period Q1 2005-Q4 2011 } \\
\hline CLI A & 0.483 & 0.699 & 0.824 & $\mathbf{0 . 8 2 5}$ & 0.652 & 0.372 & 0.053 & -0.204 & -0.324 \\
\hline CLI B & 0.532 & 0.740 & 0.879 & $\mathbf{0 . 9 0 1}$ & 0.761 & 0.504 & 0.191 & -0.085 & -0.245 \\
\hline CLI C & 0.630 & 0.808 & $\mathbf{0 . 8 9 6}$ & 0.882 & 0.710 & 0.449 & 0.144 & -0.126 & -0.289 \\
\hline
\end{tabular}

Note: Cross-correlations were calculated from time series Q1 2001-Q4 2011. Q1 and Q4 is the first and last quarter of the particular year, respectively.

Source: Own calculations.

As in the previous case, the highest correlation coefficient value was achieved in CLI B (which corresponds to CLI 2) in the first quarter. Therefore, the CLI equation is as follows:

CLI $_{\text {HUNGARY (different weights) }}=0.27496 *$ Budapest Stock index $+0.22852 *$ crude steel production $+0.24996 *$ construction labour input index $+0.24656 *$ service confidence indicator

Figure 3 depicts a Hungarian referential series evolution, i.e. CLI 2 and CLI B. We can observe that CLI 2 and CLI B have almost identical evolution in comparison to the cyclical component of GDP at constant prices $(2005=100)$. In addition, the CLI that we suggest is in advance compared to the referential series. This 
feature is the most obvious since 2007, when the CLI started to predict economic growth as well as a business cycle peak at the beginning of 2008 and consequent economic recession due to the world-wide financial and economic crisis. The CLI predicted growth and gradual expansion in the third quarter of 2009. GDP was influenced by that evolution two quarters later.

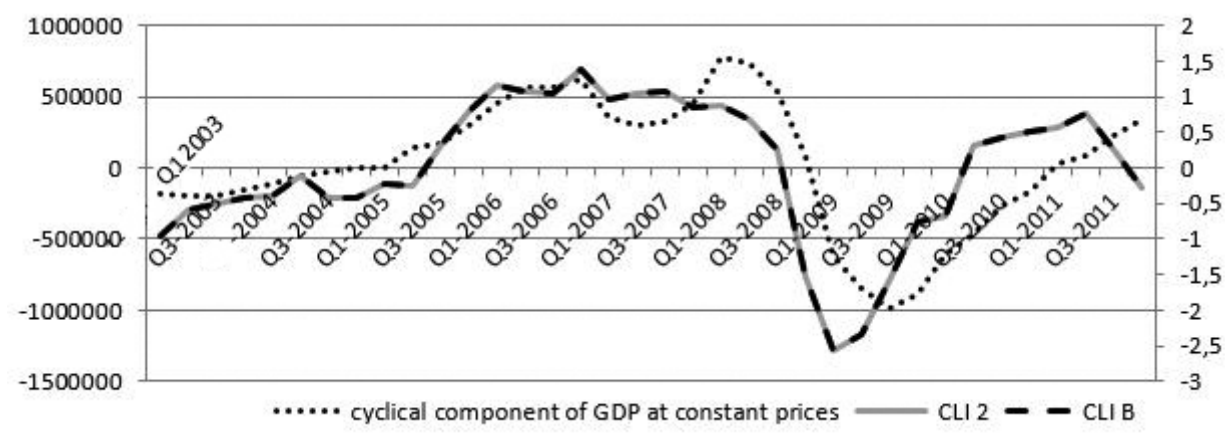

Figure 3. Referential series and the CLI evolution in the case of the same (CLI 2) and different (CLI B) weights for Hungary

Source: own calculations.

\subsubsection{Comparisons of the CLI by OECD, CLI by Eurostat and CLI suggested by} authors

We try to compare the composition and prediction capacity of our CLI and the CLI by OECD and Eurostat for the Hungarian business cycle. Comparisons of these three CLIs from the point of view of their partial components are presented in Table 9.

Despite several differences among the CLI compositions, the Budapest Stock index is involved in all three alternatives. Therefore, we can conclude that the stock index has significant prediction capacities in Hungary. All three CLIs consist of indicators linked to industry, e.g. production in the manufacturing industry in the case of the CLI by OECD, industrial confidence indicator in the CLI by Eurostat, and crude steel production in our CLI is also connected to industry.

Comparisons of the lengths of lead-times are statistically more important. The length of lead-time was analysed via the number of months or quarters. The quality of lead-time was estimated through correlation coefficients. Our conclusions are summarised in Table 10. 


\section{Table 9}

Composition of the CLI for Hungary by OECD by Eurostat and as suggested by authors

\begin{tabular}{|l|l|}
\hline CLI & Composition \\
\hline CLI by OECD & Production in manufacturing \\
& Registered number of the unemployed \\
& Number of working hours per month in manufacturing \\
& Narrow money (M1) \\
Budapest Stock Index & Central bank base rate \\
& Total of importations \\
\hline CLI by Eurostat & Industrial confidence indicator \\
& Consumer confidence indicator \\
& Construction confidence indicator \\
& Share prices index \\
\hline CLI by authors & Budapest Stock Index \\
& Crude steel production \\
& Construction labour input index \\
& Services confidence indicator \\
\hline
\end{tabular}

Sources: OECD, Eurostat, own analysis.

Table 10

Cross-correlation results of the CLIs and referential series in the case of Hungary

\begin{tabular}{|l|c|c|c|c|}
\hline \multirow{2}{*}{ Organisation } & \multicolumn{2}{|c|}{ Monthly data } & \multicolumn{2}{c|}{ Quarterly data } \\
\cline { 2 - 5 } & $\begin{array}{c}\text { Correlation } \\
\text { coefficient } \\
\text { value }\end{array}$ & Leadtime & $\begin{array}{c}\text { Correlation } \\
\text { coefficient } \\
\text { value }\end{array}$ & Leadtime \\
\hline OECD (1995-2011) & 0.755 & 3 months & - & - \\
\hline OECD (2005-2011) & 0.823 & 3 months & - & - \\
\hline OECD (2000-2011) & - & - & 0.764 & 2 quarters \\
\hline Eurostat (1996-2011) & - & - & 0.590 & 2 quarters \\
\hline Eurostat (2005-2011) & - & - & 0.701 & 2 quarters \\
\hline $\begin{array}{l}\text { Own calculation (2001-2011)- } \\
\text { same weights }\end{array}$ & - & - & 0.899 & 1 quarter \\
\cline { 2 - 5 } $\begin{array}{l}\text { Own calculation (2005-2011)- } \\
\text { same weights }\end{array}$ & - & - & 0.862 & 2 quarters \\
\cline { 2 - 5 } $\begin{array}{l}\text { Own calculation (2001-2011) - } \\
\text { different weights }\end{array}$ & - & - & $\mathbf{0 . 9 0 1}$ & $\mathbf{1}$ quarter \\
\cline { 2 - 5 } $\begin{array}{l}\text { Own calculation (2005-2011) - } \\
\text { different weights }\end{array}$ & - & - & 0.878 & 2 quarters \\
\cline { 2 - 5 } & - & - & 0.898 & 1 quarter \\
\hline
\end{tabular}

Source: Own calculations. 
The OECD observes industrial production indicator evolution as a referential series on the monthly basis. In this case, we found a three-month lead-time. The maximum correlation coefficient in the CLI by OECD was at the level of 0.755 in the time series from 1995 to 2011 and 0.823 for time series starting in 2005. Recalculation to quarters changes a lead-time to two quarters and the correlation coefficient is 0.764 . The Eurostat's referential time series is GDP cyclical component. Its time-lead is at the level of two quarters and the correlation coefficient equals to 0.590 for the time series from 1996 on. The correlation coefficient value is 0.701 in the case of the period from 2005 to 2011. Our CLI manifests shorter lead-time (1 quarter). However, its correlation coefficient is significant. It is 0.899 for a time series since 2001 or 0.901 since 2005 . Consequently, the CLI that we suggest should predict referential series evolution more precisely, but later. The highest correlation appears at period $t-1$, whereas in the OECD and Eurostat methodology they appear at $t-2$ (see Table 10). Tables 7 and 8 display that even the second highest cross-correlation value is higher in the suggested CLI than it is in the CLI by OECD or Eurostat. The main advantage of our CLI is that the high correlation coefficient value in the lead-time should minimise false signals about future economic evolution.

\section{CONCLUSIONS}

The aim of the present paper was to create our own composite leading indicator (CLI) convenient to monitor and predict Hungarian business cycles in short-run. We compared the existing CLI applied by the OECD and Eurostat with our CLI. We have analysed the size (number of lead-time months and quarters), the accuracy, i.e. quality (correlation coefficient value in a lead-time) of lead-time versus a referential series. According to our findings, our CLI forecasts the evolution of a referential series more precisely than the CLIs developed by the OECD and Eurostat. Nevertheless, from our point of view, the application of all existing CLIs at the same time can be appropriate. Consequently, the number of false signals should be reduced. The CLIs allow us to receive the first rough preliminary estimations of Hungarian economic cycles. In addition, this analysis allows us to research in detail lagging and coincident Hungarian cycle indicators. 


\section{REFERENCES}

Beneš, J. - N'Diaye, P. (2004): A Multivariate Filter for Measuring Potential Output and the NAIRU: Application to the Czech Republic. IMF Working Paper, 04(45): 1-30.

Bezděk, J. - Dybczak, K. - Krejdl, A. (2003): Cyclically Adjusted Fiscal Balance - OECD and ESCB Methods. Czech Journal of Economics and Finance, 53(11-12): 477-509.

Boschan, C. - Ebanks, W. W. (1978): The Phase Average Trend: A New Way of Measuring Economic Growth, Proceeding of the Business and Economic Statistics Section. Washinghton, D.C.: American Statistical Association.

Burns, A. F. - Mitchell, W. C. (1946): Measuring Business Cycles. Cambridge: NBER.

Conference Board (2001): Business Cycle Indicator Handbook. Economic Research. The Conference Board.

Czesaný, S. (2006): Hospodářsky cyklus (Business Cycle). Praha: Linde.

Czesaný, S. - Jeřábková, Z. (2009): Metóda konstrukce kompozitních indikátorú hospodářského cyklu pro českou ekonomiku (Methodology of the Composite Indicators Construction of the Czech Republic Business Cycle). Statistika, 1: 21-31

Economic Cycle Research Institute (2011): Turning Points \& Leading Indicators. Available at $\mathrm{http} / / /$ www.businesscycle.com/business_cycles/turning_points_leading_indicators.

Everts, M. P. (2006): Measuring Business $\bar{C}$ ycles. Berlin: Verlag im Internet GmbH.

Fabiani, S. - Mestre, R. (2000): Alternative Measures of the NAIRU in the Euro Area: Estimates and Assessment. ECB Working Paper, 17: 1-47.

Gyomai, G. - Guedette, E. (2012): OECD System of Composite Leading Indicator. Paris: Organization for Economic Cooperation and Development.

Győrffy, D. (2009): Structural Change without Trust: Reform Cycles in Hungary and Slovakia. Acta Oeconomica, 59(2): 147-177.

Hodric, R. J. - Prescott, E. C. (1997): Postwar U.S. Business Cycles: An Empirical Investigation. Journal of Money Credit and Banking, 29(1): 1-16.

Kerényi, Á. (2015): Budapest Economic Forum about the Hungarian Monetary Policy. Conference Report. Acta Oeconomica, 65(1): 143-152.

Macháčková, L. - Czesaný, S. - Sedláček, P. (2007): Monitorování a analýza hospodářského cyklu (Business Cycle Monitoring and Analysis). Praha: Český statistický úrad.

Marek, L. (2007): Statistika pro economy (Statistics for Economists). Praha: Professional Publishing.

Mester, I. T. (2007): Indicator Approach to Business Cycle Analysis. Fascicle of Management and Technological Engineering, 6(16): 2250-2256.

Mihályi, P. (1988): Cycles or Shocks: East European Investments, 1950-1985. Economics of Planning, 22(1-2): 41-56.

Moore, G. H. (1961): Business Cycle Indicators, Contributions to the Analysis of Current Business Conditions. Princeton University Press.

Nardo, M. - Saisana, M. (2005): Handbook on Constructing Composite Indicators: Methodology and User Guide. Paris: OECD Statistics Working Papers, 3.

NBS (2006): Krátkodobá prognóza ekonomického rastu (Short-Term Economic Growth Prediction). Available at http://www.nbs.sk/_img/Documents/PUBLIK/MU/06_01-2.pdf.

Nilsson, R. (2000): Confidence Indicators and Composite Indicators. Paris: OECD.

Nilsson, R. - Gyomai, G. (2007): Cycle Extraction: A Comparison of The PAT Method, the HodrickPrescott and Christiano-Fitzgerald Filters. Paris: OECD. 
Nilsson, R. - Gyomai, G. (2011): Cycle Extraction: A Comparison of the Phase Average Trend Method, the Hodrick-Prescott and Christiano-Fitzgerald Filters. Paris: OECD Statistics Working Papers, 4.

OECD (1993): Cyclical Indicators and Business Tendency Survey. Paris.

OECD (1998): OECD Composite Leading Indicators: A Tool For Short-Term Analysis. Paris.

OECD (2004): The OECD-JRC Handbook on Practices for Developing Composite Indicators. Paris: OECD Committee on Statistics.

OECD (2008): Handbook on Constructing Composite Indicators: Methodology and User Guide. Paris.

OECD (2012a): Glossary for OECD Composite Leading Indicators. Paris.

OECD (2012b): Main Economic Indicator: Composite Leading Indicators For Countries. Paris.

OECD (2013): Composite Leading Indicator for Hungary. Paris.

Ozyildirim, A. - Schaitkin, B. - Zarnowitz, V. (2009): Business Cycles in the Euro Area Defined with Coincident Economic Indicators and Predicted with Leading Economic Indicators. Luxembourg: 5th Eurostat Colloqium on Modern Tools for Business Cycle Analysis.

Saltelli, A. (2007): Composite Indicators between Analysis and Advocacy. Social Indicators Research, 81: 65-77.

Schilcht, E. (2005): Estimating the Smoothing Parameter in the So-Called Hodrick-Prescott Filter. Journal of the Japanese Statistical Society, 35(1): 99-119.

Sullivan, A. - Sheffrin, S. M. (2003): Economics: Principles in Action. New Jersey: Pearson Prentice Hall.

Tkáčová, A. (2012): Kompozitný predstihový indikátor hospodárskeho cyklu českej ekonomiky (Composite Leading Indicator of Czech Business Cycle). Politická ekonomie, 60: 590-613.

Trimbur, T. M. (2006): Detrending Economic Time Series: A Bayesian Generalization of the Hodrick-Prescott Filter. Journal of Forecasting, 4: 247-273.

Tuveri, J. P. (1997): National Accounts Central and Eastern Europe. Paris.

Zimková, E. - Barochovský, J. (2007): Odhad potenciálného produktu a produkčnej medzery v slovenských podmienkach (Estimation of Potential Output and Output Gap in Slovak Conditions). Politická ekonomie, 4: 473-489. 


\section{APPENDIX}

\section{Coincident indicators for Hungary}

\begin{tabular}{|c|c|c|c|c|c|c|c|c|c|}
\hline Indicator & $t-4$ & $t-3$ & $t-2$ & $t-1$ & $t$ & $t+1$ & $t+2$ & $t+3$ & $t+4$ \\
\hline $\begin{array}{l}\text { Production in industry, } \\
2005=100\end{array}$ & 0.11 & 0.40 & 0.65 & 0.81 & $\underline{0.84}$ & 0.70 & 0.48 & 0.25 & 0.08 \\
\hline $\begin{array}{l}\text { Production in manufacturing, } \\
2005=100\end{array}$ & 0.14 & 0.42 & 0.68 & 0.82 & $\underline{0.83}$ & 0.68 & 0.45 & 0.23 & 0.06 \\
\hline $\begin{array}{l}\text { Industrial production index, } \\
2005=100\end{array}$ & 0.10 & 0.39 & 0.65 & 0.81 & $\underline{0.84}$ & 0.70 & 0.48 & 0.26 & 0.09 \\
\hline $\begin{array}{l}\text { Sales - total retail trade, } \\
2005=100\end{array}$ & 0.23 & 0.31 & 0.44 & 0.55 & $\underline{0.66}$ & 0.65 & 0.61 & 0.48 & 0.31 \\
\hline Gross capital formation, HUF & -0.03 & 0.13 & 0.37 & 0.55 & $\underline{0.65}$ & 0.59 & 0.40 & 0.20 & 0.00 \\
\hline Changes in inventories, HUF & 0.12 & 0.24 & 0.44 & 0.57 & $\underline{0.60}$ & 0.52 & 0.30 & 0.04 & -0.21 \\
\hline $\begin{array}{l}\text { Exports of goods and services, } \\
\text { bil. HUF }\end{array}$ & 0.05 & 0.30 & 0.54 & 0.69 & $\underline{0.74}$ & 0.65 & 0.47 & 0.26 & 0.07 \\
\hline $\begin{array}{l}\text { Imports of goods and services, } \\
\text { bil. HUF }\end{array}$ & -0.01 & 0.25 & 0.51 & 0.71 & $\underline{0.79}$ & 0.71 & 0.52 & 0.30 & 0.09 \\
\hline Imports of goods, mil. HUF & -0.15 & 0.15 & 0.46 & 0.68 & $\underline{0.72}$ & 0.61 & 0.42 & 0.24 & 0.14 \\
\hline $\begin{array}{l}\text { Gross national expenditure } \\
\text { (final consumption +gross capital } \\
\text { formation), } 2005=100\end{array}$ & -0.13 & 0.08 & 0.31 & 0.55 & $\underline{0.66}$ & 0.61 & 0.47 & 0.28 & 0.13 \\
\hline $\begin{array}{l}\text { Private final consumption } \\
\text { expenditures, } 2005=100\end{array}$ & 0.01 & 0.16 & 0.34 & 0.50 & $\underline{0.59}$ & 0.57 & 0.50 & 0.37 & 0.24 \\
\hline $\begin{array}{l}\text { Industrial turnover (intermediate } \\
\text { and capital goods), total market, } \\
2005=100\end{array}$ & 0.13 & 0.41 & 0.67 & $\mathbf{0 . 8 3}$ & $\underline{0.86}$ & 0.73 & 0.50 & 0.27 & 0.09 \\
\hline $\begin{array}{l}\text { Industrial turnover (intermedi- } \\
\text { ate and capital goods), domestic } \\
\text { market, } 2005=100\end{array}$ & 0.06 & 0.30 & 0.55 & 0.74 & $\underline{0.83}$ & 0.73 & 0.55 & 0.33 & 0.14 \\
\hline $\begin{array}{l}\text { Industrial turnover (intermediate } \\
\text { and capital goods), non-domestic } \\
\text { market, } 2005=100\end{array}$ & 0.13 & 0.42 & 0.67 & 0.82 & $\underline{0.83}$ & 0.70 & 0.47 & 0.25 & 0.08 \\
\hline $\begin{array}{l}\text { Wholesale and retail sale } \\
\text { turnover (except for motor } \\
\text { vehicles and motorcycles), } \\
2005=100\end{array}$ & 0.07 & 0.28 & 0.54 & 0.77 & $\underline{0.90}$ & 0.88 & 0.76 & 0.55 & 0.34 \\
\hline $\begin{array}{l}\text { GDP Euro area } 17 \text { (constant } \\
\text { prices 2005) }\end{array}$ & 0.00 & 0.27 & 0.53 & 0.71 & $\underline{0.78}$ & 0.71 & 0.55 & 0.37 & 0.22 \\
\hline GDP 27 (constant prices 2005) & 0.03 & 0.32 & 0.58 & 0.75 & $\underline{0.81}$ & 0.72 & 0.55 & 0.37 & 0.22 \\
\hline
\end{tabular}


Lagging indicators for Hungary

\begin{tabular}{|c|c|c|c|c|c|c|c|c|c|}
\hline Indicator & $t-4$ & $t-3$ & $t-2$ & $t-1$ & $t$ & $t+1$ & $t+2$ & $t+3$ & $t+4$ \\
\hline Narrow money M1, 2005 = 100 & -0.18 & 0.06 & 0.33 & 0.57 & 0.73 & $\underline{0.76}$ & 0.71 & 0.59 & 0.45 \\
\hline Broad money M3, 2005 $=100$ & -0.55 & -0.47 & -0.36 & -0.24 & -0.09 & 0.06 & 0.25 & 0.42 & 0.57 \\
\hline $\begin{array}{l}\text { Current account balance of pay- } \\
\text { ment, mil. USD }\end{array}$ & 0.24 & 0.06 & -0.15 & -0.43 & -0.63 & -0.69 & -0.61 & -0.43 & -0.25 \\
\hline $\begin{array}{l}\text { Gross fixed capital formation, } \\
\text { HUF }\end{array}$ & -0.43 & -0.30 & -0.13 & 0.12 & 0.34 & 0.51 & 0.59 & $\underline{0.60}$ & 0.57 \\
\hline $\begin{array}{l}\text { Consumer prices (inflation), } \\
\text { (consumer prediction), } \%\end{array}$ & 0.21 & 0.28 & 0.30 & 0.25 & 0.10 & -0.10 & -0.31 & -0.51 & -0.61 \\
\hline Consumer c & 0.21 & 0.29 & 0.31 & 0.27 & 0.13 & -0.07 & -0.30 & -0.51 & -0.62 \\
\hline $\begin{array}{l}\text { Foreign official reserves, special } \\
\text { drawing rights (SRD), mil. HUF }\end{array}$ & 0.29 & 0.18 & 0.02 & -0.21 & -0.46 & -0.66 & -0.80 & -0.72 & -0.50 \\
\hline $\begin{array}{l}\text { Wholesale and retail trade em- } \\
\text { ployment, Services, } 2005=100\end{array}$ & 0.05 & 0.07 & 0.26 & 0.45 & 0.57 & $\underline{0.59}$ & 0.47 & 0.29 & 0.11 \\
\hline
\end{tabular}

Leading indicators for Hungary

\begin{tabular}{|l|c|c|c|c|c|c|c|c|c|}
\hline Indicator & $t-4$ & $t-3$ & $t-2$ & $t-1$ & $t$ & $t+1$ & $t+2$ & $t+3$ & $t+4$ \\
\hline $\begin{array}{l}\text { Budapest Stock index, 2005 } \\
100\end{array}$ & 0.58 & $\mathbf{0 . 7 7}$ & $\underline{\mathbf{0 . 8 3}}$ & 0.72 & 0.48 & 0.23 & 0.00 & -0.13 & -0.15 \\
\hline Market capitalisation, bn. Euro & 0.63 & $\underline{\mathbf{0 . 7 7}}$ & $\mathbf{0 . 7 7}$ & 0.63 & 0.44 & 0.23 & 0.07 & -0.01 & -0.03 \\
\hline $\begin{array}{l}\text { Construction labour input index, } \\
\text { total, 2005 = 100 }\end{array}$ & 0.52 & 0.61 & 0.70 & $\underline{\mathbf{0 . 7 5}}$ & $\mathbf{0 . 7 3}$ & 0.62 & 0.43 & 0.20 & -0.02 \\
\hline $\begin{array}{l}\text { Crude steel production, thou- } \\
\text { sands of tons }\end{array}$ & 0.09 & 0.31 & 0.53 & $\underline{\mathbf{0 . 6 9}}$ & $\mathbf{0 . 6 6}$ & 0.50 & 0.27 & 0.08 & -0.02 \\
\hline Industrial confidence indicator & 0.40 & 0.54 & $\underline{\mathbf{0 . 6 3}}$ & $\mathbf{0 . 6 1}$ & 0.47 & 0.23 & -0.04 & -0.26 & -0.38 \\
\hline Services confidence indicator & 0.41 & 0.60 & $\mathbf{0 . 7 1}$ & $\underline{\mathbf{0 . 7 4}}$ & 0.62 & 0.36 & 0.02 & -0.30 & -0.50 \\
\hline
\end{tabular}

